\title{
STRATEGIC UNCERTAINTY: A NEW WAY OF U.S. DIPLOMACY TOWARDS THE QATAR CRISIS
}

\author{
Andre Wirautomo \\ Faculty of Social and Political Science, International Relations Postgraduate Program, \\ University of Indonesia, Depok, Indonesia. \\ Email: andrewirautomo@gmail.com
}

\begin{abstract}
The way of U.S. diplomacy under President Trump administration declared a different approach from the Obama era. As President Trump extols unpredictability as a virtue, where Trump is more active through social media in conveying his views. That behavior considered a boomerang for U.S. diplomacy. Under President Trump's administration, many of the state statement is contradicted with the White House. The uncertainty of U.S. diplomacy is seen when the United States involved in efforts to resolve the Qatar crisis. Qatar crisis is a diplomatic crisis that occurred between Qatar and the Gulf Arab countries which reached its peak in 2017. The United States has never interfered disputes between Qatar and the Gulf Arab countries that have occurred since 2002. However, the United States increased the tension of the Qatar crisis after several tweets from President Trump criticize Qatar funds terrorism in the Middle East. Simultaneously, Secretary of State Rex Tillerson corrected President Trump's statement by expressing the U.S. is supporting Qatar and trying to help by resolving the conflict as quickly as possible. Qatar is well known as the closest ally of the United States on combating terrorism in the Middle East. The disputes between Qatar and the Gulf Arab countries considered had an impact to be interrupting the movement of the United States on combating terrorism in the Middle East which directly affects several U.S. interests in the region. Differences between President Trump and the State Department do not send a clear nor unified message that is a problem for U.S. strategy towards the Qatar Crisis. It considered as proof of the uncertainty of U.S. diplomacy under President Trump administration. Through this analysis the article seeing the uncertainty of the U.S. diplomacy strategy in resolving the Qatar crisis.
\end{abstract}

Kata kunci: Diplomatic strategy, President Trump, U.S. Foreign Policy, Qatar Crisis, Qatar Blockade

\section{INTRODUCTION}

Qatar crisis is a dispute that occurred between Qatar and the Gulf Arab countries which is Saudi Arabia, United Arab Emirates, Bahrain and Egypt. The crisis was caused by the severance of diplomatic relations by the Arab Gulf countries towards Qatar. Since the establishment of the Gulf Cooperation Council (GCC)1 on 25 May 1981, the relationship between Qatar to these countries never been better. The beginning of the dispute between Qatar and the the Gulf Arab countries can be traced from the beginning of the 20th century. At that time, disputes were still centered on border disputes and involved countries in the Gulf region. The border conflict with the Gulf Arab countries reached its peak in the early '90s where countries such as the United Arab Emirates, Bahrain and Saudi Arabia had a dispute with Qatar in determining territorial borders. The border dispute between Qatar and the UAE occurred over the region around Khawr al Udayd. The border dispute between Qatar and Bahrain occurred over the Hawar Islands region, the base of al Dibal and al Jaradah, as

16 Volume 2, Nomor 1, $2020 \mid \mathbf{R I R}$ 
well as the Zubarah region since 1936 and ended in 2001. Then border dispute occurred between Qatar and Saudi Arabia related to the existence of natural resources which for both countries is the main income for foreign exchange (Wardoyo, 2018).

During the dispute, there were several mediation efforts undertaken by other countries as an effort to maintain stability of the Gulf region. However, mediation efforts have never been succeeded. The dispute reaches its peak on 5-6 June 2017 because the Arab Gulf countries repatriated Qatar ambassador and cut diplomatic ties (Al- Jazeera, 2017). Since diplomatic ties were severed by Gulf Arab countries towards Qatar, the tension on region getting higher especially with Saudi Arabia which already involved in the cold war with Qatar since 2002 because Saudi Arabia always interfering Qatar internal affairs (Roberts, 2017). Background why the tension between these Gulf Arab countries escalated again because the four countries have claimed that Qatar worked to support terrorism, maintained too close relations with Iran and meddled in the internal affairs of their countries. Qatar's national television, Al Jazeera is accused of being responsible for funding and supporting terrorist acts that have caused instability in the Middle East (Lake, 2017). Because of that Qatar considered have been violated the rules of GCC members who should fight all forms of terrorism acts, so the Gulf Arab countries demanded Qatar to shut down Al Jazeera and all affiliated stations. Moreover, Qatar must stop diplomatic relations with Iran and expel Iranian military representatives from Qatar and limit economic cooperation. Qatar responded by rejected the accusations leveled against it as baseless. Qatar's Foreign Minister said claims made by the Gulf Arab countries are unreasonable because Qatar is one of the closest allies of the United States in fighting terrorism. Qatar is willing to negotiate with the boycotting countries and has welcomed calls from international leaders for dialogue (Khaleej Times, 2017).

The Gulf Arab countries did not trust the refutation given by Qatar, on the contrary, they asked 13 demands that must be fulfilled by Qatar if it wants to normalize relations with the Gulf Arab countries. Kuwait was chosen by the Gulf Arab countries as a mediator (Fouad, 2017). Qatar has repeatedly rejected the list of demands leveled against it because unreasonable. The list of demands such as shut down the Turkish military base who under construction in Qatar and cease all military cooperation with Turkey, closing the Al Jazeera TV channel, downgrading ties with Iran, stop meddling in other nations affairs and 
naturalizing citizens of the four blockading countries. This makes Kuwait mediation efforts to resolve the crisis of Qatar does not work at all (Feteha, Fiona \& Tarek, 2017).

The existence of the U.S. in the Middle East always influential in dealing with disputes in the region, the U.S. is expected to be a solution for resolving the Qatar Crisis. The U.S. has long had a close relationship with the Gulf Arab countries and respects their good relations by never interfering in disputes between the Gulf Arab countries. The dispute between the Gulf Arab countries always been family issues if sees from the U.S. point of view in which only related countries should solve the problem (Fouad, 2017). However, the relationship between the United States and Qatar had an awkward relationship due to the negative statement from President Donald Trump on social media. President Trump posted on Twitter that he supports the actions of Saudi Arabia blockade against Qatar and criticizes Qatar to stop funding of terrorism, this makes the tension between the United States and Qatar at the high risk.

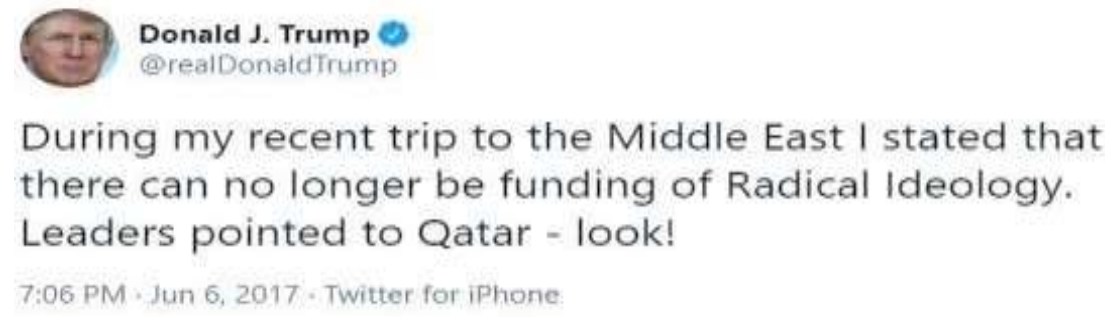

Since the blockade, Qatar had faced a food supply crisis, therefore the Qatari government is considering food aid from Iran and Turkey. It can happen because $40 \%$ of Qatar's food supply comes from Saudi Arabia. Realizing that food aid would bring close ties to Qatar and Iran, the White House immediately corrected President Trump's statement. As we know, the relationship between Iran and the U.S. has teetered for decades, therefore The U.S. does not like it if Iran had influence in the region. Shortly the White House released an official statement in responding to the Qatar crisis delivers by Secretary of State Rex Tillerson, the U.S. considers Qatar as a reliable ally in the fight against terrorism and wants to help end the Qatar Crisis.

The U.S. expects the countries to immediately take steps to de-escalate the situation and put forth a good faith effort to resolve the grievances they have with each other (Pramuk, 2017). The official statement from the White House is very surprising because it contradicts President Trump's statement had previously delivered which would not side with Qatar. 
JUNE9, $20 \pi 7$

Secretary Tillerson on U.S. Policy Toward Qatar

Secretary of State Rex Tilerson delivered a statement on US, policy toward Qatar. He called on Saudi Arabia,

United Arab Emirates, Bahrain, and Egypt to ease the blockade on Qatar, saying it hindered U.S. military efforts to

combat ISIS. In addition, Secretary Tillerson urged for "calm and thoughtful dialogue" among Arab countries in

addressing their concerns with Qatar. On June 5, 2017, Saudi Arabia, United Arab Emirates, Bahrain, and Egypt cut

diplomatic ties with Qatar, accusing it of supporting terrorism. close A

There is one big question here about miscommunication and uncertainty of the U.S. diplomacy under President Trump administration implemented the diplomatic strategy. To understand what is causes of uncertainty in the U.S. diplomatic strategy under President Trump administration, this paper will analyze further through political and theoretical aspects. The discussion through these two aspects will be divided into two parts, the first part about the disharmony of relations under President Trump administration and the second part about the U.S. national interests to be achieved towards the Qatar crisis.

\section{RESEARCH METHODS}

In order to analyze the research problem, this paper uses congruence analysis within a qualitative method. This approach serves to find the causative mechanism between conditions and the results obtained through analysis of a series of events in a case. According to Alan Bryman, qualitative research is a research strategy that usually emphasizes words and not quantification in data collection and analysis. It is inductive, constructionist, and interpretative even though qualitative researchers do not always include these three elements (Bryman, 2004).

This paper applying a qualitative study because it focuses on analyzing case studies using theory as an analytical framework to gain deeper knowledge about cases raised or debated. The case study can be interpreted as a method or strategy in research to uncover the specific case. This research uses a case study approach to focus attention on an object that is raised as a case study to be explored in depth so to be able to uncover the reality behind the phenomenon. In a qualitative study, researchers will try to understand a case by using systematic methods of observing, collecting data, analyzing information from the case. Therefore, according to Lawrence Neuman, qualitative research methods are research methods that are subjective because they place humans as the main subjects and objects in their research (Neuman, 2000).

Data collection methods used by researchers to answer the formulation of research problems with the method of library research. Data collection included both the documents 
and literature taken as secondary data. These data collected by the author through textbooks, political and economic journals, as well as news that contains the selected case studies. The data was obtained from several online libraries such as Scopus, Taylor \& Francis Online, JSTOR, and from credible media such as Al Jazeera and Reuters. Authors collected data related to the

U.S. Foreign Policy towards Qatar Crisis, news related to the U.S. want to help to resolve the Qatar Crisis and press releases from the White House related to the Qatar Crisis. After these data collected, the writer then classifies and interprets the data, and analyzes the data using the concept of national interest and draws conclusions.

\section{DISCUSSION}

\section{White House Paradox On The Qatar Crisis}

Diplomatic relations between the U.S. and Qatar began in 1972 after Qatar was granted independence by the United Kingdom in 1971. At that time the U.S. sent diplomat William A. Stoltzfus, Jr. to Doha to discuss the construction of the U.S. Embassy in Qatar. Not long after that on 24 February 1973, the U.S. Embassy officially established in Doha (US Department of State, 2019). Bilateral relations between the two countries were built with the aim of developing Qatar into one of the modern countries in the Middle East. The desire to encourage the pace of development led Qatar to establish more intensive cooperation with the United States, the form of cooperation was strategic cooperation. The strategic cooperation covers the fields of security, economy, social and politics (US Department of State, 2019). Qatar and the U.S. developed close military ties in the Gulf War I against Iraq. Qatar even built a military base in Al Udeid as a base of the U.S. military forces in the Middle East. That makes Qatar's strategic partnership has been particularly strong when the U.S. moved its central regional airbase from Saudi Arabia to Al Udeid. This move as a commitment from Qatar to support the U.S. campaign in fighting terrorism in the Middle East. The Al Udeid military base was built at a cost of up to $\$ 1$ billion and does not charge the U.S. any rent or utilities. Since then the military cooperation between Qatar and the United States has strengthened.

Besides security, cooperation between Qatar and the U.S thrive in the economic field. Qatar provides a very large income for the United States economy and vice versa. Qatar has invested a lot in the U.S. economy. For the example, economic investment is reached by Qatar Airways with Boeing when purchasing aircrafts worth up to a multi-billion dollar (Fahy, 2018). Moreover, Qatar has invested in education by build several universities 
affiliated with U.S. universities such as Georgetown, Texas A \& M and Northwestern (Fahy, 2018). In the social field, Qatar also helped the U.S when the country was hit by natural disasters. Qatar's role of philanthropist to the U.S by donating $\$ 100$ million to the US in the wake of Hurricane Katrina in 20005. Also, Qatar's governments provide medical aid to the victims of the disaster (Fahy, 2018).

Although there are many positive steps taken by Qatar to strengthen its relationship with the U.S., it certainly does not necessarily make the relations between the two countries no obstacles. Since the inauguration of Donald Trump as the new president of the U.S. in 2017, a lot of people who predict there will be disharmony on President Trump administration. The prediction was proven by many differences of an opinion issued by President Trump with Secretary of State, Rex Tillerson, and even their official statement always clashed. The disharmony on President Trump administration caused by the uncertainty of the diplomatic strategy was implemented by Trump administration from the beginning. This analysis proven by contradictive statements from the U.S. officials responded to Qatar's diplomatic ties in the Qatar crisis. When President Trump responded by sided with Saudi Arabia, on the other hand, the White House immediately responded to support Qatar and trying to help resolve the Qatar Crisis.

However, since President Trump criticizes Qatar on social media, the tweet from President Trump who supports the actions of Saudi Arabia blockade against Qatar and criticized Qatar as a funder of terrorism at a very high level. Statement from the U.S. President like covered up through the statement of the Secretary of State, Rex Tillerson Shortly afterward efforts were made immediately by the White House, through President Trump took initiative to calls the head of state in conflict. President Trump spoke with King Salman bin Abdulaziz of Saudi Arabia, Prince Mohamed bin Zayed Al Nahyan of the United Arab Emirates and Emir Tamim bin Hamad Al Thani of Qatar, expressing his concern over the dispute between Qatar and the Gulf Arab countries through the phone calls. President Trump underlined that unity in this region is very important to achieve the goals of the Riyadh Summit on combating terrorism and promote regional stability. President Trump expects this dispute can be resolved as soon as possible. President Trump believes the Gulf Arab countries have a common purpose which wants to stop all forms of financing to terrorist acts in the Middle East (White House, 2017). Another effort tried by Secretary of State, Rex Tillerson, by asking the Gulf Arab countries to lower their demands and ask more realistic 
demands to Qatar in order to be accepted by both parties. So that disputes between Qatar and Arab countries can be quickly resolved. Because if we saw 13 demands asked by the Gulf Arab countries, it can be said will be rejected by Qatar. (Reuters, 2017).

Additionally, there was pressure from the United States Senate Committee on Foreign Relations to President Trump and the U.S. Secretary of State, for serious to resolve the Qatar crisis. Senate Bob Coker threatens to put on hold of arms dealing that the U.S. had done with the Gulf Arab countries if the White House did not resolve the Qatar Crisis (Gramer and De Luce, 2017). As you know, previously the U.S. government had signed a cooperation agreement on arms sales worth up to $\$ 110$ billion with Saudi Arabia (Fouad, 2017).

President Trump who has a different mindset and different thinking with Rex Tillerson's opinion had to follow pressure from the United States Senate Committee on Foreign Relations in resolving the Qatar crisis. Rex Tillerson tries to accelerate resolve the Qatari crisis, by signing a Memorandum of Understanding (MoU) between the U.S. and Qatar to reaffirming Qatar's commitment to supporting U.S. on combat terrorism, deter criminality in the regions and promote regional security and stability. (Morello and Fahim, 2017). The U.S. Secretary of State, Rex Tillerson, hopes with this MoU can be a major step in resolving the Qatar crisis. Then the next steps from the U.S. government through Secretary of State Rex Tillerson will become a mediator to tries shuttle diplomacy with Saudi Arabia, UAE, and Bahrain.

\section{The Qatar Crisis \& Its Importance To The U.S. National Interest}

In 1980 when under President Jimmy Carter's administration, U.S. announced a doctrine Carter that aims to protect its national interests in the Persian Gulf region. It stated that was of strategic importance to the US and that the United States would use military force, if necessary, to defend its national interests in the Arab Gulf. The purpose of the national interests of the United States here is related to protecting oil fields belonging to Arab countries from the threat aggression of other countries. The U.S. commitment to the protection of Gulf oil fields was maintained by subsequent administrations (Khatib, 2017). The strategic cooperation in the military to be one of the main reasons why the U.S had good relations with the Arab Gulf countries. Moreover, the oil supply from the Gulf Arab countries is considered very valuable for the U.S. because it was an alternative energy source for the United States to build its military power. In addition, the U.S. sees the Middle East as a 
region prone to the development of terrorism. The U.S. believes, if they had good ties with the Gulf Arab countries will ease the U.S. spreading anti-terrorism campaigns in the Middle East. As the U.S. hegemony rises in the middle east, the existence of the U.S to resolve a dispute in the Middle East region certainly inseparable from efforts to fulfill its national interests.

Theoretically, to see the U.S. national interest towards the Qatar crisis, it can be analyzed through variables on the national interest. Hans J. Morgenthau explained the concept of the national interest, it contains two elements, first if that logically required and if that sense necessary, and second, that is variable and determined by circumstances. To understanding variables who determined by circumstances, national interest is consists of three variables forming by circumstances that are security identity, political \& economy identity, and cultural identity (Morgenthau, 1952).

Security identity is the national goal to protect its security and territorial integrity from the threat aggression of other countries. Although the U.S. position based on geographic location does not have territorial and sovereignty within the Arabian Gulf countries, the U.S. still had their identity security in the Middle East. The U.S. military forces were headquartered at Al Udeid military base became the main reason why the U.S. should protect the region. In addition, the Al Udeid military station has become the largest military base for U.S. troops in the Middle East. That military base has become the command center for all efforts to fight terrorism in the Middle East since the implementation of the Global War on Terror policy (Fouad, 2017).

The Qatar Crisis is hindering the presence of the U.S. troops to fight terrorism in the Middle East, even Saudi Arabia asked the U.S. to temporary move their troops from Qatar airbase during the crisis. However, the U.S. not considering moving its Central Command (CENTCOM) operation based at Al Udeid in Qatar. Former Minister of Defense's the U.S., Robert Gates said the base for U.S. military forces in a military base Al Udeid is irreplaceable. Because the location of Al Udeid is very strategic for the U.S. military forces to fight against terrorism in the Middle East (Merrill, 2017).

Political and economic identity is an identity that encompasses prosperity, wellbeing, and circumstances that present a good quality of life to a country. The stable political and economic regime will certainly create stability for the country. As said by Morgenthau refer to national interests that "The national interest is normally defined in terms of strategic 
and economic capability because international politics is seen primarily as a struggle for power between states" (Morgenthau, 1952). Therefore, the ties between politics and economics cannot be separated because complement each other as a country struggles to gain power.

The U.S. hegemony in the Middle East is at stake with the normalization ties efforts between Iran and Qatar since the Gulf Arab countries blockade. If Qatar establishes relations with Iran, this could threaten relations between the U.S. and Qatar. (Walsh, 2017). Iran is well known as the main enemy that always disrupts the U.S. hegemony in the Middle East. Therefore, this has led to behavior change from the U.S. to support Qatar in resolving the Qatar crisis as an effort to maintained close relations with Qatar. The U.S which is known to have long-established good relations with Qatar certainly does not want to lose its influence on the country due to Iran's proximity to Qatar.

Besides normalization ties efforts between Iran and Qatar that will interfere with US influence, there are other political factors that make the U.S. must support Qatar in resolving the Qatar crisis. There was domestic political pressure from United States Senate Committee on Foreign Relations, Senator Bob Coker stated that Congress promised not to approve a trade agreement for arms deal worth the US \$ 110 billion if the White House did not resolve the Qatar Crisis (Fouad, 2017). This prompted President Trump to calls out a meeting between the leaders of the disputing countries so that the Qatar crisis could be resolved as soon as possible. Because this arms trade agreement is very important if seeing the nominal, it can be said as the largest arms deal between the U.S. and Saudi Arabia.

When talking about The U.S. economic regime influence in the Middle East, it is no secret that Qatar as one of the best business partners for the United States in that region. Trade relations between the U.S. and Qatar have been established since 1992 in which both countries agreed to the Defense Cooperation Agreement. The U.S. and Qatar have agreement related to arms trade since 2008, even previously the U.S. and Qatar have reached a cooperation agreement related to the purchase of F-15 aircraft worth US\$ 12 billion even though the country still on the crisis (McCarthy, 2017). This data proves that the U.S. certainly does not want to lose its business partners because of the Qatar Crisis which imposed an economic blockade on Qatar would certainly affect the economic conditions of Qatar which indirectly also impacted on the U.S. as its closest business partner. 
Table 1. US-Qatar Arms Dealing Deal

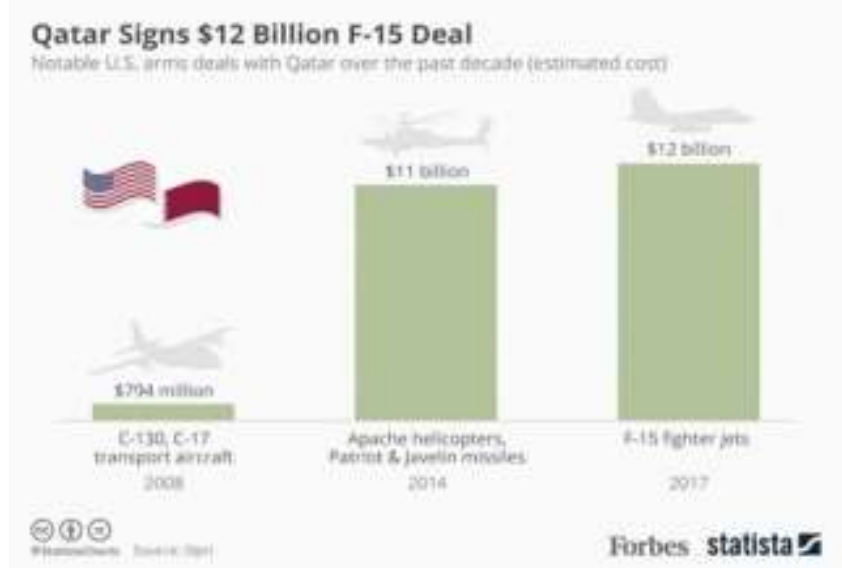

Cultural identity is an identity that encompasses the welfare of the people of a country to ensure prosperity for its people, by seeing the prevailing norms, culture, and wellpreserved tradition. Based on this, the national interests of a country must be able to guarantee prosperity and security for the people both nationally and internationally. The existence of the U.S. in the Middle East always influential in dealing with disputes in the region certainly does not want to ruin the tradition due to the prolonged disputes between Qatar and the Gulf Arab countries. The identity of the U.S. as a guarantor of stability in the region would certainly be tarnished if the U.S. did not help in resolving disputes in the region.

Therefore, the U.S. will continue to support Qatar ended the crisis as quickly as possible so that the tension of the Gulf Arab region can be normal again. Rex Tillerson as a mediator in this crisis asked the Gulf Arab countries send more realistic demands to Qatar. According to Tillerson, this is the only way can accelerate the process of resolving disputes between Qatar and the Gulf Arab countries (Fouad, 2017).

After analyzing the case study with three variables related to the national interests of the U.S. in resolving the Qatar crisis, it can be seen the reasons for the changes in the behavior of the U.S. government. At first, the behavior of the U.S government showed to not take sides with Qatar as conveyed through a statement from President Trump through social media that criticized Qatar, but not long after that the U.S. changed its statement to be supportive and want to help Qatar in resolving the crisis. This changing behavior can happen in diplomatic strategy because there are several national interests from the U.S. that are threatened as the disputes continue. 


\section{CONCLUSION}

The diplomatic strategy implemented by a country is certainly influenced by various factors in its implementation which are to fulfill the national interests of the state. Because the national interests of the state are always oriented towards achieving personal interests (self-interest oriented), therefore national interests can be used to explain and understand the behavior of the state. The U.S. under President Trump administration experienced this in which the personal interests of the head of state exceeded the national interests of his own country. This causes a contradiction in diplomatic strategies which will be implemented by the U.S. government. Uncertainty in the U.S. diplomacy strategy clearly seen when the Trump administration responded towards the Qatar crisis. The existence of a contradictory statement between the President and the Secretary of State is considered as a failure of diplomacy under President Trump's administration. The U.S. government aware of this and try to improve it in order to achieve the national interest of the U.S in the Gulf Arab region. In addition to the miscommunication in the Trump administration, the presence of pressure to fulfill national interests is considered as the other factors causing the uncertainty of the U.S. diplomacy strategy.

Theoretically, the paper agrees with Hans J. Morgenthau, about the definition of national interest are the state's goal in protecting physical identity, political and economic identity, and culture identity from other state interference. Through those instruments can lead to changes in the behavior of the United States in addressing the Qatar Crisis. National interests are an important instrument that underlies a country's foreign policymakers in determining the direction of its policies. The foreign policy later will become guidelines for the state to implement it as a diplomatic strategy. Some of America's diplomats are warning if the U.S. diplomacy under President Trump administration still uncertainty about their diplomatic strategy would give a serious impact on foreign service morale and the integrity of U.S. diplomacy so that sooner or later American diplomacy will crumbled under Trump.

\section{REFERENCES}

Al-Jazeera. (2017). Saudi Arabia, UAE, Egypt, Bahrain cut ties to Qatar. [Online] Available at http://www.aljazeera.com/news/2017/06/saudi-arabia-uae-egyptbahrain-cut-ties-qatar-170605031700062.html accessed on 4 Mei 2018.

Fahy, John. (2018). International Relations and Faith-based Diplomacy: The Case of Qatar.The Review of Faith \& International Affairs.

Feteha, Ahmed, Fiona. M. dan Tarek. El-T. (2017). Qatar Crisis Is Back to Square One

$$
\text { as Economy Shows the Strain. [Online] Available at }
$$


https://www.bloomberg.com/news/articles/2017-07-30/saudi-bloc-ministers meetto- discuss-next-step-in-qatar-crisis accessed on 4 Mei 2018.

Fouad, Sam. (2017). The Qatar Dispute Is Hindering Our Ability to Fight ISIS. [Online] Available at http://www.newsweek.com/qatar-dispute-hindering-our-ability-fightisis- 642548 accessed on 4 Mei 2018.

Gramer, Robbie and De Luce, Dan. (2017). Corker: No More U.S. Arms Sales to Gulf Until Qatar Crisis Solved [Online] Available at https://foreignpolicy.com/2017/06/26/no- more-arms-sales-to-gulf-until-qatarcrisis-solved-senate-foreign-relations-saudi-arabia-united-arab-emirates-middleeast/ accessed on 4 Mei 2018.

Khaleej Times. (2017). Sheikh Tamim denies Qatar has links to terrorism. [Online] Available at http://www.khaleejtimes.com/region/qatar/sheikh-tamim-denies-qatarhas-links-to- terrorism accessed on 4 Mei 2018.

Khatib, Dania Koleilat. (2017). US-Arab Gulf Relations amidst Regional and Global Changes.Routledge Taylor \& Francis Group.

Lake, Eli. (2017). The Ex-Journalist Who Says Al-Jazeera Aids Terrorists - Bloomberg. [Online] Available at https://www.bloomberg.com/view/articles/2017-0623/the- former-anchor-who-says-al-jazeera-aids-terrorists accessed on 4 Mei 2018.

McCarthy, Niall. (2017). The U.S. Seals \$12 Billion F-15 Deal With Qatar Amid Gulf Crisis. [Online] Available at https://www.forbes.com/sites/niallmccarthy/2017/06/15/the-u-s- seals-12-billion-f-15deal-with-qatar-amid-gulf-crisis-infographic/\#7c416cab65f2 accessed on 4 Mei 2018. 